J. Amer. Soc. Hort. Sci. 115(1):45-51. 1990.

\title{
Microsprinkler Irrigation and Growth of Young 'Hamlin' Orange Trees
}

\author{
Thomas E. Marler'and Frederick S. Davies \\ Department of Fruit Crops, University of Florida, Gainesville, FL 32611
}

Additional index words. Citrus sinensis, C. aurantium, roots, canopy

\begin{abstract}
Growth responses of young 'Hamlin' orange [Citrus sinensis (L.) Osbeck] on sour orange (C. aurantium L.) trees to microsprinkler irrigation were studied under field conditions from 1985 to 1987 to determine the mostefficient irrigation rates and duration. Trees were irrigated when available soil water depletion (SWD) reached $20 \%$ (high frequency), $45 \%$ (moderate frequency), and $65 \%$ (low frequency). Trees at the moderate and low levels received 49\% and $13 \%$, respectively, as much irrigation water as the high treatment. Canopy volume, trunk cross-sectional area, dry weight, shoot length, leaf area, total root dry weight and volume, and new root dry weight were similar for the high and moderate levels in 2 of 3 years, but were significantly reduced at the low level. Summer and fall growth flushes were delayed or did not occur at the moderate and low levels. More than $90 \%$ of root dry weight was within $80 \mathrm{~cm}$ of the trunk at the end of the first growing season.
\end{abstract}

Several studies have been conducted comparing growth and development of young citrus trees using various irrigation scheduling methods in attempts to increase irrigation efficiency. Leyden (1975) compared strip, ring, and drip irrigation schedules on newly planted 'Star Ruby' grapefruit trees in Texas. Drip irrigation used $82 \%$ and ring irrigation $75 \%$ less water than strip irrigation without adversely affecting tree growth. Smajstrla et al., (1985) found that growth of newly planted 'Valencia' orange trees was greater when irrigations were scheduled at - $20 \mathrm{kPa}$ soil matric potential than at $-40 \mathrm{kPa}$ or when the soil around the root zone was maintained weed-free.

Irrigation method and scheduling directly affect soil water content and indirectly affect edaphic factors such as physical impedance, fertility, and aeration, thus altering root growth and distribution. Irrigation influences root growth or root density of many fruit corps, including citrus (Bielorai, 1982; Bielorai et al., 1981, 1984; Hilgeman and Sharp, 1970; Rodney et al., 1977). Irrigation also affects root distribution in the soil profile (Cahoon et al., 1961; Hilgeman et al., 1969; Hilgeman and Sharp, 1970). Knowledge of root distribution of young citrus trees is useful in management decisions concerning microsprinkler irrigation patterns and durations, and placement of soil-sensing devices for monitoring soil water status.

An estimated 6 to 10 million young citrus trees are planted in Florida annually (Jackson et al., 1986), with most receiving some type of micro-irrigation. However, water requirements,

Received for publication 6 Sept. 1988. Univ. of Florida Journal Series no. 9269. The cost of publishing this paper was defrayed in part by the payment of page charges. Under postal regulations, this paper therefore must be hereby marked advertisement solely to indicate this fact.

'Present address: Fairchild Tropical Garden, 11935 Old Cutler Rd., Miami, FL 33156. irrigation scheduling, and growth responses to microsprinkler irrigation have not been studied under long-term field conditions. Moreover, we found no information on microsprinkler irrigation effects on root growth and distribution for young citrus in Florida's subtropical climate and sandy soil. We conducted this field study to determine: 1) the level of soil water depletion at which irrigation should be scheduled to maximize growth while minimizing water use by young citrus trees, and 2) the effect of three irrigation regimes on root growth and distribution.

\section{Materials and Methods}

\section{Site and soil characteristics}

Experiments were conducted at the Horticultural Research Unit near Gainesville, Fla., from 1985 to 1987. Soil type was Kanapaha sand (loamy, siliceous, hyperthermic, Grossarenic, Paleaquults). Particle size distribution was $93.4 \%$ sand, 3.9\% silt, and $2.7 \%$ clay. The soil had $11.3 \%$ field capacity, $2 \%$ permanent wilting point, $1.56 \mathrm{~g} \cdot \mathrm{cm}^{-3}$ mean bulk density, 6.4 $\mathrm{pH}, 0.65 \%$ organic matter content, and $9.3 \mathrm{~cm} \cdot \mathrm{hr}^{-1}$ saturated hydraulic conductivity.

Soil beds (16.75-m width x $0.60-0.75-\mathrm{m}$ height $\times 85-\mathrm{m}$ length) were constructed in Mar. 1985 to facilitate drainage and provide space for root development. Ground water fluctuations were monitored through observation wells in tree rows. Depths to water table in the tree row averaged $1.1 \mathrm{~m}$ during the rainy season (June through September), with a minimum of $0.45 \mathrm{~m}$. Natural bahiagrass ground cover was developed between rows and was mowed as needed, while tree rows were maintained weed-free with herbicides. Rainfall was recorded daily by a rain gauge located $\approx 200 \mathrm{~m}$ east of the experimental site. 


\section{Plant material and experimental design}

Commercially grown, bare-rooted 'Hamlin' orange trees on sour orange rootstock were planted in 1985, 1986, and 1987 in double-row beds oriented north to south with $7.6 \mathrm{~m}$ between rows and $4.0 \mathrm{~m}$ between trees. A randomized complete-block design with four blocks and six single-tree replications per treatment per block was used in 1985 and 1986. A completely randomized desire with 13 single-tree replicates per treatment was used in 1987 because the block effect was not significant in 1985 and 1986. Trees were planted in May 1985 and 1986 and Apr. 1987. All trees were irrigated every 2 days during an establishment period (10 to 14 days). Trees were fertilized by hand 2 weeks after planting and four to five times per season thereafter (Koo et al., 1984), and received 1.8 to $2.3 \mathrm{~kg} /$ tree per season of $8 \mathrm{~N}-2.6 \mathrm{P}-6.6 \mathrm{~K}-2 \mathrm{Mg}-0.2 \mathrm{Mn}-0.12 \mathrm{Cu}-0.2 \mathrm{Zn}-$ $1.78 \mathrm{Fe}$ granular fertilizer.

\section{Irrigation treatments}

The irrigation system was designed to monitor and control individual treatments using flow meters and pressure gauges controlled by gate valves. Water was supplied through three 1.9-cm (i.d.) black polyethylene tubes (one for each treatment) that ran the full length of the bed, allowing unrestricted randomization. Water containing $287 \mathrm{mg}$ total dissolved solids/liter was applied to $\approx 5 \mathrm{~m}^{2}$ (at operating pressure of $138 \mathrm{kPa}$ ) at 38 liters $\cdot \mathrm{hr}^{-1}$ through one $90^{\circ}$ Maxijet microsprinkler emitter (Thayer Industries, Dundee, Fla.) positioned $1 \mathrm{~m}$ northwest of each tree.

Scheduling was based on soil water content determined by neutron scattering (Hillel, 1982) using a Troxler Model 1255 neutron probe (Research Triangle Park, N.C.). Access tubes were driven into the soil at four $(1985,1986)$ or 3 (1987) randomly chosen trees per treatment and positioned $35 \mathrm{~cm}$ northeast of each tree and $1 \mathrm{~m}$ from emitters. Measurements at a depth of $30 \mathrm{~cm}$ were made daily or as needed during the rainy season. The soil volume around the tree was irrigated to field capacity when a prespecified available soil water depletion (SWD) level was reached at any of the four sites in 1985 and 1986 or based on the average of the three neutron probe readings in 1987. Three levels of irrigation were chosen based on previous studies with young (Smajstrla et al., 1985) and mature (Koo, 1963) citrus trees. Treatments included high (20\% SWD), moderate (45\% SWD), and low (65\% SWD) irrigation frequencies.

The amount of irrigation water needed for each treatment to bring the soil back to field capacity was determined during the first few irrigations in 1985. Soil water content was monitored with the neutron probe at 15-min intervals following an irrigation. By initially varying the length of irrigation time, the approximate length of time needed for each treatment to return the soil water content from a given SWD level to field capacity was determined.

\section{Plant measurements}

Initial measurements. Canopy height and width were measured at planting, and canopy volume was calculated as (4/ $3)(3.14)(1 / 2 \mathrm{H})(1 / 2 \mathrm{~W}){ }^{2}$, where $\mathrm{H}=$ height and $\mathrm{W}=$ width (Westwood, 1978). This formula most closely approximates the canopy shape of a young tree, which is taller than it is wide. Trunk diameter was measured in two directions $5 \mathrm{~cm}$ above the bud union with a hand-held caliper and trunk cross-sectional area was calculated. Measurements were made on the same days as canopy measurements. Total shoot length was measured for each tree with a ruler within 1 week after planting.
Randomly selected root systems of $10(1985,1986)$ and five (1987) trees per treatment were dyed before planting by dipping roots for $15 \mathrm{sec}$ in a $1 \%$ solution of safranin-0, as described by Kaufmann (1968). In addition, root volume of these same trees was measured by water displacement before planting.

Seasonal measurements. Trees generally flushed three times during each season. Dates of commencement of shoot growth in each of the three flushes were recorded for each tree at intervals of $\approx 7$ days throughout the season. The percentage of actively growing trees in each irrigation treatment and at each date was calculated from these measurements.

Final measurements. Canopy volume and trunk cross-sectional area were measured in the field in December of each year before root excavation of the majority of the plant population. In 1985 and 1986, 20 and 21 trees and, in 1987, five trees per treatment were excavated with a shovel. A circular trench was dug $40 \mathrm{~cm}$ deep and $120 \mathrm{~cm}$ from the trunks. The few roots extending beyond this distance were individually recovered by excavation. The entire shallow root system was recovered almost intact by undercutting it to a depth of $40 \mathrm{~cm}$ until the sand loosened, exposing the roots. This operation was not difficult due to the loose, sandy nature of the soil. Intact trees were taken indoors for measurements.

Leaf area per tree was calculated from leaf fresh weight using

Table 1. Amount of water applied and number of irrigations per season as related to soil water depletion for young 'Hamlin' orange trees.

\begin{tabular}{|c|c|c|c|c|c|c|}
\hline \multirow{2}{*}{$\begin{array}{l}\text { Soil water } \\
\text { depletion } \\
(\%)\end{array}$} & \multirow{2}{*}{$\begin{array}{l}\text { Irrigation } \\
\text { frequency }\end{array}$} & \multirow{2}{*}{$\begin{array}{l}\text { Irrigations/ } \\
\text { season }^{2}\end{array}$} & \multicolumn{2}{|c|}{$\begin{array}{c}\text { Water } \\
\text { applied/ } \\
\text { tree }^{y}\end{array}$} & \multicolumn{2}{|c|}{$\begin{array}{l}\text { Water applied/ } \\
\text { season/tree }^{z}\end{array}$} \\
\hline & & & liter & $\mathrm{mm}^{\mathrm{x}}$ & liter & $\mathrm{mm}^{\mathrm{x}}$ \\
\hline 20 & High & $31 \pm 2$ & 38 & 7.5 & $1174 \pm 87$ & $233 \pm 17$ \\
\hline 45 & Moderate & $11 \pm 2$ & 50 & 10.0 & $571 \pm 121$ & $113 \pm 24$ \\
\hline 65 & Low & $2 \pm 1$ & 76 & 15.1 & $151 \pm 76$ & $30 \pm 15$ \\
\hline
\end{tabular}

${ }^{2}$ Mean of data from 1985,1986 , and $1987 \pm$ SE.

yData from 1985 only. Required to return soil water to field capacity. BBased on wetted area of $\approx 5 \mathrm{~m}^{2}$.

Table 2. Growth characteristics of young 'Hamlin' orange trees as related to irrigation based on soil water depletion, 1985-1987.

\begin{tabular}{|c|c|c|c|c|c|}
\hline $\begin{array}{c}\text { Soil } \\
\text { water } \\
\text { depletion } \\
(\%)\end{array}$ & $\begin{array}{c}\text { Canopy } \\
\text { volume } \\
\left(\mathrm{m}^{3}\right)\end{array}$ & $\begin{array}{l}\text { Trunk } \\
\text { cross- } \\
\text { sectional } \\
\text { area } \\
\left(\mathrm{cm}^{2}\right)\end{array}$ & $\begin{array}{c}\text { Canopy } \\
\text { dry wt } \\
\text { (g) }\end{array}$ & $\begin{array}{l}\text { Shoot } \\
\text { length } \\
\text { (cm) }\end{array}$ & $\begin{array}{l}\text { Leaf } \\
\text { area } \\
\left(\mathrm{m}^{2}\right)\end{array}$ \\
\hline \multicolumn{6}{|c|}{1985} \\
\hline 20 & 0.57 & 5.1 & 425 & 951 & 1.3 \\
\hline 45 & 0.52 & 4.9 & 426 & 951 & 1.2 \\
\hline 65 & $0.33 * *$ & $4.2^{* *}$ & $337^{* *}$ & $752^{* *}$ & $1.0^{* *}$ \\
\hline \multicolumn{6}{|c|}{1986} \\
\hline 20 & 0.51 & 4.9 & 379 & 950 & 1.3 \\
\hline 45 & 0.54 & 4.8 & 383 & 943 & 1.3 \\
\hline 65 & $0.31^{* *}$ & $4.2^{* *}$ & $300^{* *}$ & 894 & $0.9 * *$ \\
\hline \multicolumn{6}{|c|}{1987} \\
\hline 20 & 0.56 & 4.7 & 393 & 1429 & 1.4 \\
\hline 45 & 0.37 & $3.8^{*}$ & $259^{* *}$ & $937^{*}$ & $0.7^{*}$ \\
\hline 65 & 0.36 & $3.3^{*}$ & $230 * *$ & $872^{*}$ & $0.5^{*}$ \\
\hline
\end{tabular}

${ }^{\mathrm{z}}$ Means of 20,21 , and 5 trees/treatment in 1985, 1986, and 1987, respectively.

${ }^{*}, * *$ Response is significant when compared with the $20 \%$ soil water depletion treatment by the Williams method at $P=0.05$ or 0.01 , respectively. 


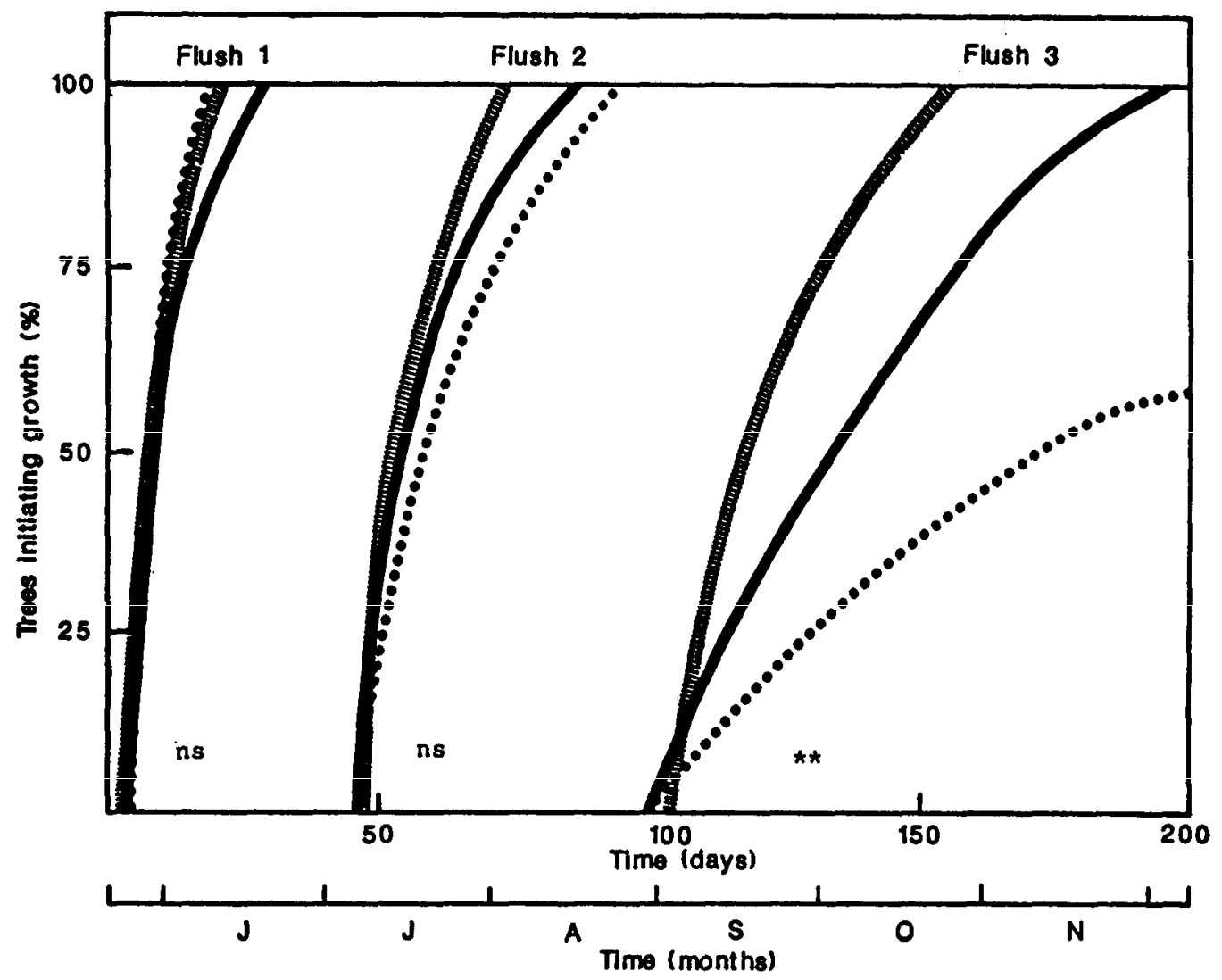

Fig. 1. Microsprinkler irrigation and cumulative percentage of young 'Hamlin' orange trees growing during the 1985 season; ( $20 \%$ soil water depletion $(\mathrm{SWD}),(\boldsymbol{m})=45 \%$ SWD, $(\bullet \bullet)=65 \%$ SWD.

Ns," Nonsignificant or significant at $P=0.01$, respectively, according to analysis of covariance test of homogeneity of the three equations within each flush. Coefficients of determination $\left(r^{2}\right)$ ranged from 0.80 to 0.97 .

a linear regression equation, $\mathrm{y}=0.00416 \mathrm{x}-0.53, r^{2}=0.93$ ( $\mathrm{y}=$ leaf area in $\mathrm{m}^{2}, \mathrm{x}=$ leaf weight in $\left.\mathrm{g}\right)$. This equation was obtained from previous sampling of the entire foliage on eight 'Hamlin' orange trees, where leaf area was measured using a LI-COR Model LI-3000 leaf area meter (Lincoln, Neb.) Total shoot length for each tree was measured with a ruler following leaf removal.

Canopy dry weight was determined by oven drying at $80 \mathrm{C}$ for 1 to 3 days.

Total root volume as determined by water displacement was measured on randomly chosen trees on which initial root volume was determined. New roots that developed during the experimental period were easily distinguished from dyed roots on these trees, and were oven-dried and weighed separately.

Lateral root distribution was determined on 10 (1985) and five $(1986,1987)$ root systems per treatment (not necessarily the same trees as chosen randomly for root volume and new root growth determination in 1985 and 1986). Root systems were separated into three concentric zones ( 0 to 40,41 to 80 , and $>80 \mathrm{~cm}$ ) from the trunk. Root distribution was determined on a dry-weight and percentage basis. Roots of all excavated trees were oven-dried at $80 \mathrm{C}$ for 3 days for dry-weight determination.

\section{Data analysis}

The percentage of each treatment population growing throughout the season was analyzed using linear, quadratic, and cubic regression models. Models with the highest level of significance and best fit for each treatment population were chosen.
Within each growth flush, the three equations were tested by analysis of covariance for homogeneity to test the hypothesis that the equations could be used to estimate the same population,

Canopy and root dry weight and leaf area were tested by analysis of variance. Canopy volume, trunk cross-sectional area, shoot length, and root volume were subjected to analysis of covariance to standardize differences in initial plant measurements. Where irrigation levels differed, Williams' test (Williams, 1971) was used to compare means. This test is useful in cases where curve-fitting and regression analysis are difficult due to a small number of treatment levels. In this instance, the most frequent (high) level was compared with the two lower irrigation levels.

Lateral root distribution was analyzed by a split-plot analysis with irrigation treatments as main plots and lateral zones as subplots. Root percentage distribution among zones was analyzed in the same manner following arcsin transformation.

\section{Results and Discussion}

\section{Irrigation amount and frequency}

One-half as much water per tree was needed to return the high irrigation treatments to field capacity as the low one (Table 1). Using 38 liter $\cdot \mathrm{hr}^{-1}, 90^{\circ}$ emitters resulted in irrigation durations of $1.0,1.3$, and $2.0 \mathrm{hr}$ for the high, moderate, and low treatments, respectively. On average, about 15 times as many irrigations per season were required for the high as for the low treatments. During dry periods, irrigations averaged 2 to 3 days apart in the high and 4 to 6 days apart for the moderate treat- 


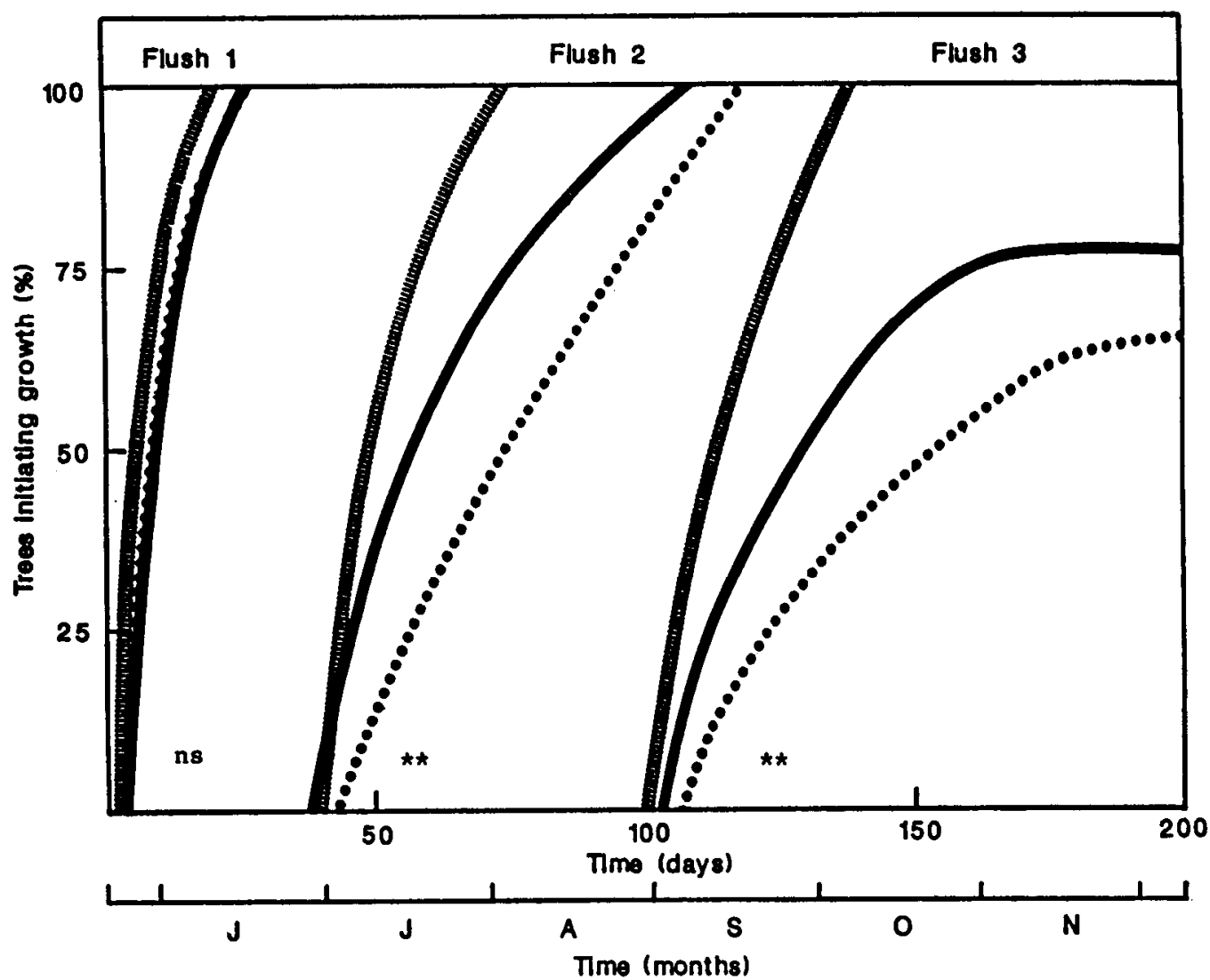

Fig. 2. Microsprinkler irrigation and cumulative percentage of young 'Hamlin' orange trees growing during the 1986 season; ( $20 \%$ soil water depletion (SWD), $(\square)=45 \%$ SWD, $(\cdots \bullet)=65 \%$ SWD.

Ns," Nonsignificant or significant at $P=0.01$, respectively, according to analysis of covariance test of homogeneity of the three equations within each flush. Coefficients of determination $\left(r^{2}\right)$ ranged from 0.86 to 0.99 .

ment. Rainfall typically interrupted the drying cycles of the low treatment. Trees in the moderate and low treatments received $49 \%$ and $13 \%$, respectively, as much water as those in the high treatment (Table 1).

\section{Canopy measurements}

Final. Final canopy size was not different for trees in the high and moderate treatments in 1985 or 1986 (Table 2). In the low treatment, however, canopy volume, trunk cross-sectional area, dry weight, total shoot length, and leaf area were significantly smaller as compared to the high treatment in 1985. Similarly, in 1986, trees in the low treatment had significantly less canopy volume, trunk cross-sectional area, dry weight, and leaf area than in the high treatment. Irrigation treatment effects on canopy growth followed a different pattern in 1987. Both the moderate and low treatments reduced trunk cross-sectional area, dry weight, shoot length, and leaf area when compared with the high treatment.

The difference in growth response in 1987 may have been due to the generally poorer quality of nursery trees used in that year. Severe defoliation occurred after transplanting trees from the nursery to the field, inducing a spring flush with an average of 68 shoots per tree. This was more than three times the number of shoots in spring flushes of trees in 1985 and 1986 (17 and 16). This phenomenon in 1987 may have resulted in depletion of stored reserves.

Seasonal. More than two-thirds of the trees in 1985 initiated their first growth flush the last week in May, and all had begun growth by 25 June (Fig. 1). Initiation of the second flush oc- curred from 12 July to 19 Aug. Irrigation treatments did not alter the dates of initiation in either flush. Initiation of the third flush occurred over a longer period than for the other two. The entire population of trees receiving the high irrigation treatment initiated growth by October. The percentage of trees initiating this flush in the moderate and low treatments was delayed, however, and $\approx 40 \%$ of the trees in the low treatment did not produce the third flush. The shapes of curves in flush three differed significantly among irrigation treatments.

Initiation of the first growth flush in 1986 and 1987 was not affected by irrigation treatment (Figs. 2 and 3). The two subsequent flushes were initiated over longer time intervals in both years, and the shapes of the curves in flushes two and three differed significantly among treatments. The percentage of trees initiating growth in the moderate and low treatments was delayed. About $25 \%$ and $35 \%$ of the trees under moderate and low irrigation had not initiated the third flush by the end of the season in 1986. Dates of flush growth were earlier in 1987 due to the earlier planting date. Trees in all treatments produced flushes three times in 1987, also possibly due to the earlier planting date and resulting longer season.

Some trees at $20 \%, 45 \%$, and $65 \%$ SWD started growing at about the same time, but initiation of new shoot growth in trees irrigated at $45 \%$ and $65 \%$ SWD was extended over a longer time than for trees irrigated at 20\% SWD (Figs. 1-3). Similarly, Cooper et al. (1969) suggested that a prolonging of the quiescence period between growth flushes of citrus commonly occurs in response to drought, possibly resulting from decreased levels of available reserves, since a considerable reduction in $\mathrm{CO}_{2}$ 


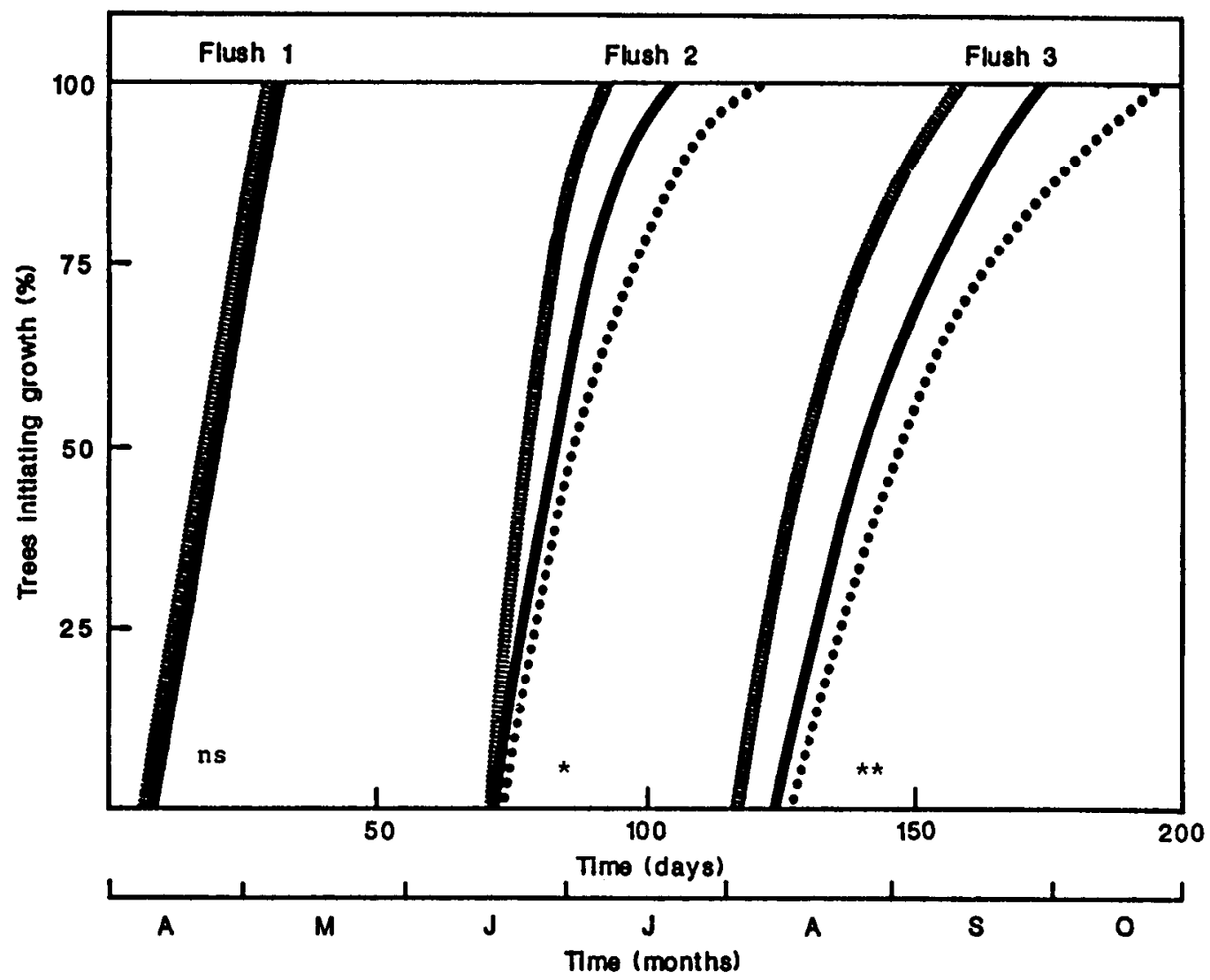

Fig. 3. Microsprinkler irrigation and cumulative percentage of young 'Hamlin' orange trees growing during the 1987 season; ( mum ) = $20 \%$ soil water depletion (SWD), $(-)=45 \%$ SWD, $(\cdots)=65 \%$ SWD.

Ns, "**Nonsignificant or significant at $P=0.05$ or 0.01 , respectively, according to analysis of covariance test of homogeneity of the three equations within each flush. Coefficients of determination $\left(r^{2}\right)$ ranged from 0.78 to 0.97 .

Table 3. Root characteristics of young 'Hamlin' orange on sour orange rootstock as related to irrigation based on soil water depletion, 1985-1987.

\begin{tabular}{|c|c|c|c|}
\hline $\begin{array}{l}\text { Soil water } \\
\text { depletion } \\
(\%)\end{array}$ & $\begin{array}{c}\text { Total root } \\
\text { dry wt } \\
(\mathrm{g})^{z}\end{array}$ & $\begin{array}{c}\text { New root } \\
\text { dry wt } \\
\text { (g) }\end{array}$ & $\begin{array}{c}\text { Root } \\
\text { volume } \\
\left(\mathrm{cm}^{3}\right)^{\mathrm{y}}\end{array}$ \\
\hline \multicolumn{4}{|c|}{1985} \\
\hline 20 & 348.7 & 156.3 & 1189.2 \\
\hline 45 & 333.9 & 158.8 & 1058.4 \\
\hline 65 & 297.3 & 139.4 & $920.5 * *$ \\
\hline \multicolumn{4}{|c|}{1986} \\
\hline 20 & 342.1 & 191.0 & 1180.9 \\
\hline 45 & 337.8 & 185.4 & 1396.5 \\
\hline 65 & $262.1^{*}$ & $128.2^{*}$ & $854.3^{* *}$ \\
\hline \multicolumn{4}{|c|}{1987} \\
\hline 20 & 257.8 & 126.2 & 858.2 \\
\hline 45 & $169.4^{*}$ & $84.8^{*}$ & $559.7^{*}$ \\
\hline 65 & $159.6^{*}$ & $81.2^{*}$ & $554.0^{*}$ \\
\hline
\end{tabular}

${ }^{\mathrm{z}}$ Mean of 20,21 , and 5 trees/treatment in 1985, 1986, and 1987, respectively.

yMean of 10, 10, and 5 trees/treatment in 1985, 1986, and 1987, respectively.

*,**Response is significant when compared with the $20 \%$ SWD treatment by the Williams method at $P=0.05$ or 0.01 , respectively.

assimilation occurs in response to increased soil water deficit (Marler and Davies, 1989). Similarly, Van Noort (1969) reported that shoot length and leaf number per shoot of citrus depended on available reserves. Perhaps a critical level of avail- able reserves must be met before subsequent shoot growth begins.

The delay in growth flush was a more pronounced response to irrigation frequency than individual shoot and leaf growth. Individual leaf and shoot expansion rates and ultimate sizes were in many instances little affected by irrigation treatment (Marler, 1988). Decreased total shoot length with decreasing irrigation frequency (Table 2) was largely a result of fewer shoots per tree (each having similar expansion rates) as the season progressed.

\section{Root measurements}

Root dry weight and volume. Irrigation treatments had variable effects on root dry weight and volume from year to year (Table 3). Dry weights were not affected in 1985, but root volumes were decreased significantly at the low compared to the high irrigation treatment. In contrast, irrigation levels significantly affected root growth in 1986 and 1987 . Trees at the low irrigation level in 1986 had less total root dry weight, new root dry weight, and root volume than those in the high treatment. Both moderate and low treatments in 1987 decreased total root dry weight, new root dry weight, and root volume compared to the high treatment. Canopy growth responses followed similar patterns in all years (Table 2).

Root volume ranged from 850 to $1190 \mathrm{~cm}^{3}$ in 1985 and 1986 , and from 550 to $860 \mathrm{~cm}^{3}$ in 1987, while dry weight ranged from 260 to $350 \mathrm{~g}$ in 1985 and 1986, and from 160 to $260 \mathrm{~g}$ in 1987 for 7- to 8-month-old trees. These values are in close agreement with those of Bevington and Castle (1982) for 13-month-old 'Valencia' orange on 'Carrizo' citrange or rough lemon trees 
Table 4. Lateral root distribution (dry-weight and percentage basis) of young 'Hamlin' orange on sour orange rootstock as related to irrigation based on soil water depletion, 1985 -1987

\begin{tabular}{|c|c|c|c|c|c|c|c|c|}
\hline \multirow{3}{*}{$\begin{array}{c}\text { Soil water } \\
\text { depletion } \\
(\%)\end{array}$} & \multicolumn{6}{|c|}{ Distance from trunk (cm) } & \multirow{3}{*}{$\begin{array}{c}\text { Total } \\
\text { (g) }\end{array}$} & \multirow[b]{3}{*}{$\mathrm{SE}^{\mathrm{y}}$} \\
\hline & \multicolumn{2}{|c|}{$0-40$} & \multicolumn{2}{|c|}{$41-80$} & \multicolumn{2}{|c|}{$>80$} & & \\
\hline & $\mathrm{g}$ & $\%$ & g & $\%$ & $\mathrm{~g}$ & $\%$ & & \\
\hline \multicolumn{9}{|c|}{1985} \\
\hline 20 & 292.0 & 83.9 & 40.0 & 11.5 & 16.0 & 4.6 & 348.0 & 10.0 \\
\hline 45 & 257.3 & 80.0 & 44.9 & 13.9 & 19.7 & 6.1 & 321.9 & 10.0 \\
\hline 65 & 256.3 & 82.0 & 40.6 & 13.0 & 15.3 & 5.0 & 312.2 & 10.0 \\
\hline Mean & 269.0 & 82.0 & 41.9 & 12.8 & 17.1 & 5.2 & 328.0 & \\
\hline $\mathrm{SE}^{\mathrm{x}}$ & 10.4 & & 10.4 & & 10.4 & & & \\
\hline \multicolumn{9}{|c|}{1986} \\
\hline 20 & 239.8 & 68.3 & 72.6 & 20.1 & 44.0 & 11.6 & 356.4 & 13.1 \\
\hline 45 & 189.2 & 70.7 & 53.8 & 19.1 & 27.4 & 10.2 & 270.4 & 13.1 \\
\hline 65 & 163.0 & 69.2 & 51.0 & 21.6 & 21.6 & 9.2 & 235.6 & 13.1 \\
\hline Mean & 197.3 & 68.6 & 59.1 & 20.6 & 31.0 & 10.8 & 287.4 & \\
\hline $\mathrm{SE}^{\mathrm{X}}$ & 20.0 & & 20.0 & & 20.0 & & & \\
\hline \multicolumn{9}{|c|}{1987} \\
\hline 20 & 197.0 & 76.4 & 44.0 & 17.1 & 16.8 & 6.5 & 257.8 & 13.5 \\
\hline 45 & 132.6 & 78.3 & 28.2 & 16.6 & 8.6 & 5.1 & 169.4 & 13.5 \\
\hline 65 & 124.8 & 78.0 & 26.0 & 16.4 & 8.8 & 5.6 & 156.4 & 13.5 \\
\hline Mean & 151.5 & 77.5 & 32.7 & 16.7 & 11.4 & 5.8 & 195.6 & \\
\hline $\mathrm{SE}^{\mathrm{x}}$ & 15.3 & & 15.3 & & 15.3 & & & \\
\hline
\end{tabular}

${ }^{z}$ Means of $10(1985)$ and $5(1986,1987)$ root systems/treatment.

$\mathrm{y}_{\mathrm{SE}}$ for comparison of zone means within rows.

${ }^{x_{S E}}$ for comparison of irrigation treatment means within columns.

grown in root observation chambers. The comparable root sizes in the two studies, despite the much shorter growing period in this field study, may be due to rootstock differences or the allowance of unrestricted root development under field conditions.

In all three years, root growth decreased at the lowest irrigation frequency, but was similar for the two highest frequencies in two of three years. Similarly, less growth in response to decreased soil water has been observed for citrus trees of various ages (Bevington and Castle, 1985; Bielorai, 1982; Bielorai et al., 1981; Hilgeman and Sharp, 1970; Rodney et al., 1977).

Lateral root distribution. The interaction for irrigation treatment by lateral zone for root dry weight was significant in all three years. Total root dry weight was higher for the high treatment than for the low and moderate treatments in all three years, primarily due to a greater concentration of roots for that treatment within $40 \mathrm{~cm}$ of the trunk (Table 4). Root weight in the 41- to 80 - and $>80-\mathrm{cm}$ zones was not affected by irrigation treatment, nor was lateral root distribution on a percentage basis.

Across all irrigation treatments and years, dry weights and percentages decreased significantly with increased distance from trunk (Table 4). The percentage of root dry weight within 40 $\mathrm{cm}$ of the trunk ranged from $68 \%$ to $84 \%$, between 41 and 80 $\mathrm{cm}$ from $11 \%$ to $21 \%$, and $>80 \mathrm{~cm}$ from $4 \%$ to $11 \%$. These values are similar to those of Aiyappa and Srivastava (1965), who found that healthy 1.5 -year-old mandarin trees in India had $60.0 \%, 14.7 \%, 13.2 \%$ and $12.1 \%$ of their root dry weight in 0- to 30-, 30- to 60-, 60- to 90-, and > 90-cm concentric zones respectively. Circular trench profiles corroborated these findings in that root concentrations and root length density were more than three times greater at 40 than at $80 \mathrm{~cm}$ from the trunk (Marler, 1988). Fibrous root dry weight also decreased with greater distance from the trunk, although to a lesser extent (Marler, 1988).
Maximum spread of lateral roots pooled over the three seasons averaged $137 \mathrm{~cm}$ for the high treatment, 127 for moderate, and $121 \mathrm{~cm}$ for low treatments. In comparison, 2-year-old 'Valencia' orange trees in Australia had a lateral root spread of 150 $\mathrm{cm}$ (Till and Cox, 1965), and 1.5-year-old mandarin trees in India, $160 \mathrm{~cm}$ (Aiyappa and Srivastava, 1965).

Fibrous roots accounted for $27 \%$ of the total root dry weight under these conditions (data not shown), which is similar to that observed by Bevington and Castle (1982) in Florida, but less than found for mandarin seedlings $(37.5 \%)$ growing in India (Aiyappa and Srivastava, 1965).

There is considerable controversy over the optimum microsprinkler irrigation pattern to use for young citrus trees. On average, the root zone occupied an area of $\approx 5.2 \mathrm{~m}^{2}$ in this study, with $64 \%$ covered by the $90^{\circ}$ emitters. Furthermore, $96 \%$ of the root dry weight was within the wetted zones, indicating that $90^{\circ}$ microsprinkler emitters placed $1 \mathrm{~m}$ from the tree cover the majority of the young tree's roots after one season. Tree growth comparisons using $90^{\circ}$ and $180^{\circ}$ emitters during the second season of growth also suggest $90^{\circ}$ emitters are adequate for up to 2 years under Florida conditions (Marler, 1988).

The optimum level of irrigation in this study was between $20 \%$ and $45 \%$ SWD, suggesting that microsprinkler irrigation every 4 to 6 days at $45 \%$ SWD is as effective as irrigating every 2 to 3 days at $20 \%$ SWD. This schedule results in a considerable reduction in irrigation water required. However, the final growth flush of some trees may be reduced at the moderate irrigation level, probably because of inherent variability in SWD among trees within the treatment.

\section{Literature Cited}

Aiyappa, K.M. and K.C. Srivastava. 1965. Studies on root system of Coorg Mandarin seedling trees. Indian J. Hort. 22:122-130.

Bevington, K.B. and W.S. Castle. 1982. Development of the root 
system of young 'Valencia' orange trees on rough lemon and Carrizo citrange rootstock. Proc. Fla. State Hort. Soc. 95:33-37.

Bevington, K.B. and W.S. Castle. 1985. Annual root growth pattern of young citrus trees in relation to shoot growth, soil temperature, and soil water content. J. Amer. Soc. Hort. Sci. 110:840-845.

Bielorai, H. 1982. The effect of partial wetting of the root zone on yield and water use efficiency in a drip- and sprinkler-irrigated mature grapefruit grove. Irr. Sci. 3:89-100.

Bielorai, H., S. Dasberg, Y. Erner, and M. Bruin. 1981. The effect of various soil moisture regimes and fertilizer levels on citrus yield response under partial wetting of the root zone. Proc. Intl. Soc. Citricult. 2:585-589.

Bielorai, H., S. Dasberg, Y. Erner, and M. Bruin. 1984. The effect of fertigation and partial wetting of the root zone on production of Shamouti oranges. Proc. Intl. Soc. Citricult. 1:118-121.

Cahoon, G. A., M.R. Huberty, and M.J. Garber. 1961. Irrigation frequency effects on citrus root distribution and density. Proc. Amer. Soc. Hort. Sci. 77:167-172.

Cooper, W. C., R.H. Young, and W.H. Henry. 1969. Effect of growth regulators on bud growth and dormancy in citrus as influenced by season of year and climate. Proc. First Intl. Citrus Symp. 1:301314.

Hilgeman, R. H., W.L. Ehrler, C.E. Everling, and F.O. Sharp. 1969. Apparent transpiration and internal water stress in Valencia oranges as affected by soil water, season, and climate. Proc. First Intl. Citrus Symp. 3:1713-1723.

Hilgeman, R.H. and F.O. Sharp. 1970. Response of 'Valencia' orange trees to four soil water schedules during 20 years. J. Amer. Soc. Hort. Sci. 95:739-745.

Hillel, D. 1982. Introduction to soil physics. Academic, London.

Jackson, L. K., W.R. Summerhill, and J.J. Ferguson. 1986. A survey of young citrus tree care practices in Florida. Proc. Fla. State Hort. Soc. 99:44-46.

Kaufmann, M.R. 1968. Water relations of pine seedlings in relation to root and shoot growth. Plant Physiol. 43:281-288.

Koo, R.C.J. 1963. Effects of frequency of irrigations on yield of orange and grapefruit. Proc. Fla. State Hort. Soc. 76:1-5.

Koo, R. C. J., C.A. Anderson, I. Stewart, D.P.H. Tucker, D.V. Calvert, and H.K. Wutscher. 1984. Recommended fertilizers and nutritional sprays for citrus. Fla. Agr. Expt. Sta. Bul. 536D.

Leyden, R.F. 1975. Comparison of three irrigation systems for young citrus trees. J. Rio Grande Valley Hort. Soc. 29:25-29.

Marler, T.E. 1988. Growth of young 'Hamlin' orange trees as influenced by microsprinkler irrigation, fertilization, and nursery tree type. PhD Diss., Univ. of Florida, Gainesville.

Marler, T.E. and F.S. Davies. 1989. Soil water content and leaf gas exchange of young, field-grown 'Hamlin' orange trees. Proc. Intl. Soc. Trop. Hort. 32:45-50.

Rodney, D. R., R.L. Roth, and B.R. Gardner. 1977. Citrus responses to irrigation methods. Proc. Intl. Soc. Citricult. 1:106:110.

Smajstrla, A. G., L.R. Parsons, K. Aribi, and G. Velledis. 1985. Responses of young citrus trees to irrigation. Proc. Fla. State Hort. Soc. 98:25-28.

Till, M.R. and J.B. Cox. 1965. A guide to cultural practices for young citrus trees. J. Agr. South Austral. Dept. Agr. 68:232-233.

Van Noort, G. 1969. Determining the potential production of citrus trees in a given environment. Proc. First Intl. Citrus Symp. 1:345350 .

WestWood, M.N. 1978. Temperate zone pomology. Freeman, New York.

Williams, D.A. 1971. A test for differences between treatment means when several dose levels are compared to a zero dose control. Biometrics 27:103-117. 